\title{
The Determinants Of Web-Based Investor Relations Activities By Companies Operating In Emerging Economies: The Case Of Jordan
}

\author{
Naser M. AbuGhazaleh, Gulf University for Science and Technology, Kuwait \\ Amer Qasim, American University of Madaba, Jordan \\ Clare Roberts, University of Aberdeen Business School, UK
}

\begin{abstract}
Using a multi-theoretical approach, this study seeks to examine the determinants of corporate web-based investor relations (IR) activities for companies listed on Amman Stock Exchange. Jordan provides an interesting context to pursue the objectives of this study because it provides insights into how listed companies are voluntarily responding to recent government and financial market regulators' initiatives to encourage the use of the internet and to keep financial market participants informed about corporate activities. A survey analysis is conducted to examine online reporting practices of Jordanian listed companies. The explanatory analysis relies on logistic, ranked and normal scores ordinary least squares $(O L S)$ regression analyses and identifies ten explanatory variables that may affect the existence and level of web-based IR disclosure; company size, profitability, government ownership, institutional ownership, number of shareholders, growth prospects, age, industry type, auditor type, and equity need. Results reveal that the existence of web sites is positively related to company size and industry (Financials) while the extent of webbased IR disclosure is significantly positively related to size, governmental ownership, institutional ownership, number of shareholders, and industrial type (Financials); however, it is negatively related to company age.
\end{abstract}

Keywords: Internet Financial Reporting; Investor Relations; Online Reporting; Voluntary Disclosure; Jordan

\section{INTRODUCTION}

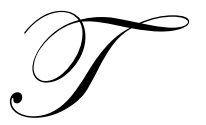

he Hashemite Kingdom of Jordan is a developing middle-income country with few natural resources, but a highly educated workforce. After he came to power in 1999, King Abdullah II started to promote the idea that information and communication technology (ICT) can be used as a means of development and providing an exceptional opportunity for the country to ensure a favourable place in the international economy (Al-Jaghoub and Westrup, 2003). In response, a number of major ICT based initiatives were launched with the aim of transforming the country to e-Jordan (REACH, 2000; Ciborra and Navarra, 2005). For example, the government launched new programmes such as the E-Government programme and Education Initiative which included modernising and computerising the education process.

The Ministry of Information and Communication Technology (MoICT) was also established in 2002 as the governmental organisation responsible for articulating policies in the areas of information technology (IT), telecommunications, and post. The Ministry's agenda started with the "Connecting Jordanians" vision with the aspiration of creating a knowledge-based economy and wider access to information to communities, businesses, and families across the Kingdom. 
In response to these initiatives, internet usage has grown rapidly from 127,300 users in 2000 , or a penetration rate of $2.4 \%$ of the population, to $1,500,500$ or $23.7 \%$ of the population in $2009^{[1]}$. This makes Jordan the sixth highest user among the Arab Middle Eastern countries. The financial market has also made information availability and transparency the first priority and, in parallel to these moves to increase the use of the internet, the government has been actively attempting to attract foreign investments to the Kingdom. This has resulted in a high level of international investment in the country so that by 2008, $46.6 \%$ of the Amman Stock Exchange was owned by non-Jordanians.

The presence of the internet as a unique channel for disseminating up-to-date information of any type and any format as well as the ability of the internet to make this information available for anyone who has online access, regardless of geographical distances, have made the internet an attractive tool for companies to enhance their reporting practices and broaden their business and investment activities (Adams and Frost, 2004; Beattie and Pratt, 2001; 2003; Xiao et al 2002). However, despite both government initiatives and very high levels of foreign investments in Amman Stock Exchange, many companies are still not using the internet for investor relations activities.

The objective of this study is therefore twofold. Firstly, to explore the online status of Jordanian listed companies and the extent to which websites are utilized to disclose IR-related information. Secondly, to investigate factors influencing companies' decisions to both have a website and to disclose IR-related information.

The study contributes to the literature on internet financial reporting (IFR) in developing countries in general, and in Jordan in particular by examining the determinants of web-based IR activities in the Jordanian context using a multi-theoretical approach. It also offers valuable insights into the characteristics of those companies that do and do not meet national and international investors' demands for online information. Jordan provides an interesting context to pursue the objectives of this study because it provides insights into how listed companies are voluntarily responding to recent government and financial market regulators' initiatives to encourage the use of the internet and to keep financial market participants informed about corporate activities.

The remainder of this paper is organised as follows. Section 2 explores the impact of the internet on IR activities. Section 3 presents the main findings of prior research and develops the research hypotheses. Section 4 describes the research methodology employed to empirically test the hypotheses. Section 5 reports the results and Section 6 concludes the study.

\section{THE IMPACT OF THE INTERNET ON IR ACTIVITIES}

The FASB (2000) lists four motives for companies to use the internet to disseminate financial information:

1. To reduce the cost of and time taken to distribute information.

2. To communicate with previously unidentified users of information.

3. To enhance traditional disclosure practices and increase the amount and type of data disclosed.

4. To improve access to potential investors for small companies.

Companies can both broaden and segment their disclosure audience, enhance disclosure timeliness, and improve communication quality not only by increasing the amount of information made available but also by establishing a two way dialogue with stakeholders and by using audio and video presentations (Lymer at al., 1999; Deller et al., 1999; Beattie and Pratt, 2003). Looking specifically at financial information, placing IR information online offers equal access to all users and reduces the information advantage of institutional investors (Wagenhofer, 2003), thus providing the opportunity to enhance global links and increase the user population (Lymer at al., 1999). In addition, real-time reporting helps to reduce the 'timeliness' problem inherent in the periodic time-frames of traditional print media (FASB, 2000). Furthermore, the internet allows increased corporate disclosure as its virtually unlimited storage capacity permits cost-effective provision of press releases and additional information services (Deller et al., 1999). In this vein, Hedlin (1999) argues that one of the greatest advantages of internet reporting is the opportunity to download files for further analysis. While Xiao et al. (2002) argues that, instead of the traditional one-way provider-dominated reporting process, the internet provides the opportunity for interactive communication. 
Corporate websites thus have the potential to be far more than simply a vehicle for shareholder dialogue. They can also be seen as a tool for impression management. Bart (2001) argues that websites can be used for electronic window dressing, influencing stakeholders' impressions of firms' legitimacy, innovation and attitude to social responsibility. While the freedom to publish information on a company's website could be abused with the information provided being deliberately misleading, it facilitates the use of web-based impression management to reflect companies' images among their stakeholders, and to develop a strong identity (Winter et al., 2003).

Recognising the potentials and advantages of the internet for IR does not imply that it is flawless. Concerns regarding the credibility and integrity of publishing share price sensitive information on the company's website without a proper monitoring system have been frequently raised (e.g., Debreceny and Gray, 1999; Hodge, 2001; and Lymer and Debereceny, 2003). Similarly, the problems inherent in linking audited financial statements to unaudited websites have been viewed as a major drawback of using the internet in business reporting (FASB, 2000).

\section{PRIOR STUDIES AND HYPOTHESES DEVELOPMENT}

\subsection{Internet Financial Reporting Practices}

The earlier studies on internet financial reporting (IFR) practices, not surprisingly, report that not all companies had an internet presence (e.g., Ashbaugh et al. (1999) and Ettredge et al. (2001), with respect to USA; Brennan and Kelly (2000), Ireland; Craven and Marston (1999), UK; Gowthorpe and Amat (1999) Spain; Marston (2003) Japan: Oyelere et al. (2003) New Zealand). More recent studies indicate a similar position still exists in the Arab world (e.g., Al-Htaybat (2006), Jordan; Desoky (2009), Egypt; Hussainey and AlNodel (2008) Saudi Arabia; Mohamed et al. (2009) Oman). While the majority of these studies primarily report current practices, a few instead employ a logit analysis and investigate whether IFR practices can be predicted. Not surprisingly, all agree that company size is a significant determinant of IFR practices (Ashbaugh et al., 1999; Craven and Marston, 1999; Oyelere et al., 2003). In addition, Oyelere et al. (2003) report that ownership spread (the proportion of shares held by the top $40 \%$ shareholders) is also an important factor in determining IFR practices for firms listed on the New Zealand Stock Exchange.

\subsection{The Extent of Internet Financial Reporting}

The majority of studies examining the extent of IFR practices have considered web-based IR disclosures to be a part of companies' voluntary disclosure strategy. Most have therefore relied on the propositions provided by economic theories such as the cost-benefit, agency and signalling theories. The primary theoretical foundation of these studies is the notion of information asymmetry between management and ownership (Debreceny et al, 2002). According to this view, corporations adopt new disclosure practices including internet-based reporting to mitigate the adverse effects of information asymmetry.

However, the specific factors examined by these studies have varied quite considerably. For example, Geerings et al. (2003) and Craven and Marston (1999) examine only the importance of size and industry for firms listed on the Euronext Stock Exchange and the UK, respectively, and report both variables to be significant; while Bonson and Escober (2006) also examine auditor type and report all three variables (size, industry and auditor type) to be important in explaining the extent of IFR practices for firms listed in Eastern Europe. Other studies have employed a wider range of independent variables. For example, Ettredge et al. (2002) examine the importance of the need for equity capital, performance, size, and information asymmetry. They report all factors (except performance) to be significant for a sample of US listed firms. Marston and Polei (2004) find that size, foreign listing and free float are significant in explaining IFR practices for a sample of firms listed in Germany; while Xiao et al (2004) report that government ownership, industry, leverage and company size are significant in explaining IFR practices in China. In a different study, Debreceny et al. (2002) examine IFR of 660 large companies in 22 countries to identify the firm, and environmental determinants of IFR. They report that company size, listing on US stock exchanges and technology (industry) are firm specific determinants of IFR. They also report the overarching disclosure environment of a country to be an important environmental driver for IFR presentation and less strongly for IFR content. Similarly Bollen et al (2006) in a study of six developed countries report that firm size, level of internationalization (foreign listing and foreign revenue), free float, country' disclosure environment, technology 
and growth rate (ratio of market value to book value) are significantly related to the level of IR activities on the internet.

Studies conducted by Abdelsalam and Street (2007), Abdelsalam et al. (2007), Kelton and Yang (2008), and Abdelsalam and El-Masry (2008) instead investigated the impact of a number of corporate governance characteristics on levels of IFR. For example, in the UK Abdelsalam et al. (2007) report a significant positive relationship between IFR and board independence and a significant negative relationship with board shareownership. In a US-based study Kelton and Yang (2008) report significant positive relationships between levels of IFR and governance index, board independence, audit committee expertise, and audit committee meetings, but a significant negative relationship with block-holdings ${ }^{[2]}$.

This study differs from relevant prior research in that it, using a multi-theoretical approach, examines a wide range of determinants hypothesized to affect the existence/extent of web-based IR activities in the Jordanian context which has not been extensively examined before. Jordan provides an interesting context to pursue the objectives of this study because it provides insights into how listed companies are voluntarily responding to recent government and financial market regulators' initiatives to encourage the use of the internet and to keep financial market participants informed about corporate activities.

\subsection{Hypotheses Development}

This study proposes that internet adoption should be viewed not only in terms of economic theories of disclosure but also in terms of institutional theory. Particularly important in this context are likely to be pressures, whether formal or informal, exerted by other institutions upon which the company is dependent or cultural expectations of society (coercive isomorphism) and mimetic isomorphism or the pressures to imitate similar, larger or more successful companies in order to decrease uncertainty or to appear more legitimate (DiMaggio and Powell, 1983). Adoption of the internet may also be viewed as an innovation suggesting that the diffusion of innovations theory is also helpful in explaining corporate practices (Rogers, 1995). Not only are factors such as managerial attitudes towards change and the degree of centralisation likely to be important, but also of importance is the extent to which the innovation offers a relative advantage over alternatives and its ability to meet the needs of potential users. The following factors are hypothesized to affect the existence/level of web-IR disclosures:

\section{Company Size}

Company size has generally been found to be a significant and positive predictor of IFR practices, indicating that larger companies adopt better reporting practices (e.g., Craven and Marston, 1999; Ashbaugh et al., 1999; Pirchegger and Wagenhofer, 1999; Ettridge et al., 2002; Debreceny et al., 2002; Marston, 2003; Marston and Polei, 2004; Xiao et al., 2004; Bonson and Escobar, 2006; Chan and Wickramasinghe, 2006; Al-Htaybat, 2005, Bollen et al.,2006). According to diffusion of innovations theory, company size is the best predictor of organizational innovativeness because it acts as a surrogate measure for several dimensions, such as total resources, employees' technical expertise, and organizational structure (Rogers, 1995). Larger companies can better afford innovations and are more likely to have the necessary technological and personal resources (Flanagin, 2000). Larger companies are likely to also have greater agency and political costs, both also suggesting the greater use of internet reporting. The above discussion results in the following hypothesis (stated in the alternative form):

H1: Ceteris paribus, company size is positively related to the existence /extent of web-IR disclosure.

\section{Company Performance}

From a signalling theory perspective, more successful companies have the incentive to distinguish themselves from less successful ones in order to lower their cost of capital (e.g. Healy and Palepu, 2001; Marston and Polie, 2004). However, prior studies have reached inconsistent results regarding this variable. For example, while Ashbaugh et al. (1999), Marston and Polei (2004), Xiao et al (2004) and Bollen et al (2006) find that performance is not a significant determinant of IFR practices, Aly et al (2010) find it significant in explaining IFR practices in Egypt. Based on the conflicting empirical results, this study examines the relationship between web-IR 
disclosure and company performance but does not predict the direction of the association. The following hypothesis is therefore proposed:

H2: Ceteris paribus, company profitability is related to the existence/ extent of web-IR disclosure.

\section{Government Ownership}

Stemming from an institutional theory perspective, coercive isomorphism resulting from formal and informal pressures exerted on organizations may affect their decision to adopt new technologies. Companies with a significant government ownership are therefore likely to want to be seen to respond to government initiatives regarding internet usage. From an agency perspective these companies may also have higher political costs. The above discussion results in the following hypothesis (stated in the alternative form):

H3: Ceteris paribus, the proportion of shares held by the government is positively related to the existence/ extent of web-IR disclosure.

\section{Institutional Ownership}

Normative isomorphism suggests that professionalism pressures may influence the adoption of websites. In this regard, the existence of institutional shareholders, particularly prestigious or influential institutions, may exert a normative pressure on a company to adopt new technologies. Similarly, information asymmetry problems may increase as institutional ownership increases with disclosure on the internet being seen as a way of reducing information asymmetry. The above discussion results in the following hypothesis (stated in the alternative form):

H4: Ceteris paribus, the proportion of shares held by institutional investors is positively related to the existence/ extent of web-IR disclosure.

\section{Number of Shareholders}

Generally, a large shareholder base may create more pressures on companies to improve disclosure practices (Abdelsalam and Street, 2007; Haniffa and Cooke, 2002). Ferguson et al. (2002) argue that as the number of shareholders increase and ownership becomes more widespread, monitoring costs and demands for additional information increase. A large shareholder base may also increase a company's visibility in the market and as a result, voluntary disclosure may be used to reduce political costs. The diffusion of innovations theory also explains how the perceived benefits of an innovation and the degree to which it is compatible with the company's needs may affect its use (Rogers, 1995). Therefore, using websites as a tool for disseminating and communicating IR information may be more cost-efficient and so more attractive for companies with a large shareholder base (Brennan and Hourigan, 2000). The above discussion results in the following hypothesis (stated in the alternative form):

H5: Ceteris paribus, the number of shareholders is positively related to the existence/ extent of web-IR disclosure.

However, the number of shareholders is likely to be correlated with company size. To remove the impact of company size, the number of shareholders was measured as the natural logarithm of the number of shareholders of a company minus the natural logarithm of the mean number of shareholders of all companies in the same asset deciles $^{[3]}$ (Bushee et al., 2003; Abdelsalam and Street, 2007).

\section{Company Age}

The diffusion of innovations theory predicts that older companies will be more resistant to change including the adoption of new technologies (Flanagin, 2000). In contrast, newer organizations may use new technologies as a strategy for defining a niche or to achieve a competitive advantage (Flanagin, 2000). Stemming from a capital need theory, companies recently listed on a stock exchange may wish to raise additional capital and so may disclose more information compared with older, better known companies to reduce uncertainty about their 
operations and increase investor's confidence (Omar, 2007). Based on these arguments, it is expected that newly listed companies are more likely to disclose more information than older listed companies. The above discussion results in the following hypothesis (stated in the alternative form):

H6: Ceteris paribus, company age is negatively related to the existence/ extent of web-IR disclosure.

Company age was measured as the number of years since a company has been listed on the Amman Stock Exchange as proposed by Haniffa (1999), Al-Htaybat (2005), and Omar (2007).

\section{Growth Prospects}

Previous studies suggest that companies with higher growth prospects and more intangibles arising from factors related to technology, corporate strategy, or human resources are more likely to exhibit a high market to book value ratio (Debreceny et al., 2002). These firms may attempt to mitigate information asymmetry by making disclosures through additional means (Xiao et al., 2004; Bollen et al., 2006; Abdelsalam et al., 2007; and Kelton and Yang, 2008).

However, a firm's decision to disclose information to investors may also be influenced by the concern that such disclosures can damage its competitive position in the market. According to Healy and Palepu (2001), firms may not disclose information if it harms their competitive position, even if it makes it more costly to raise additional equity. Debreceny et al., (2002) argue that this is especially of concern to companies with high growth potential, hence these companies may instead disclose less information. Based on the competing arguments, this study examines the relationship between web-IR disclosure and growth prospects but does not predict the direction of the association. The following hypothesis is therefore proposed:

H7: Ceteris paribus, company "growth prospects" is related to the existence /extent of web-IR disclosure.

Following Debreceny et al. (2002), Xiao et al. (2004), Bollen et al. (2006) Abdelsalam et al. (2007) and Kelton and Yang (2008), this variable is measured as the ratio of market capitalization to the book value of net assets as on the last trading day of 2006.

\section{Industry}

Institutional theory proposes that organizations are deeply influenced by organizations around them. Previous studies examining the mimetic behaviour of organizations argue that organizational behaviour is influenced by the general trends observed in the industry (Craven and Marston, 1999; Marston, 2003; Xiao et al., 2004; AlHtaybat, 2005; Bonson and Escobar, 2006; and Chan and Wickramansinghe, 2006). In addition, Watts and Zimmerman (1986) argue that the sensitivity of the industry in which a company operates may influence its disclosure practices. Stemming from this argument, the political cost hypothesis suggests that firms in industries that are more politically vulnerable may use voluntary disclosure to minimise political costs. However, there is no consensus regarding which industries may disclose the most. For example, Marston (2003), Xiao et al. (2004), and Abdelsalam and Street (2007) predict that companies in "high tech" industries are more likely to use the internet for financial reporting to show their technological awareness. Chan and Wickramasinghe (2006) predict that due to the recent growth in E-commerce and internet banking, financial institutions and banks are more likely to utilise IFR, while Abdelsalam et al. (2007) predict that manufacturing companies are more flexible in adopting IFR.

In the Jordanian context, companies in the financial sector (banks and insurance companies) are expected to be more involved in web-based IR activities than companies in other sectors to meet the demands of international clients (institutions or individuals). In addition, the financial sector in Jordan is considered to be both more competitive than other sectors and more in the public eye being considered a pillar of the Jordanian investment environment. The above discussion results in the following hypothesis (stated in the alternative form):

H8: Ceteris paribus, the Financials industry (banks and insurance) is positively related to the existence /extent of web-IR disclosure. 


\section{Auditor Type}

The diffusion of innovations theory introduced the role of the "change agent" in affecting the decision to adopt new technologies. The "change agent" is likely to be a charismatic person who shifts a company's attention to current techniques and methods that may be implemented in the company. This is consistent with Xiao et al. (2004) who argue that international auditing firms may be "change agents".

From an agency theory perspective, companies hire auditors to reduce conflict between managers and shareholders. Accordingly, companies may appoint one of the big international auditing firms to reduce high agency costs (Chow, 1982; Francis and Wilson, 1988 Giner, 1997). In addition, Xiao et al (2004) argue that big auditing firms are more likely to facilitate the diffusion of IFR. Firstly, auditor reputation can provide some protection against the uncertainty and loss of control resulting from online reporting. Secondly, they can serve as role models and provide implementation assistance. The above discussion results in the following hypothesis (stated in the alternative form):

H9: Ceteris paribus, the use of a Big 4 audit firm is positively related to the existence / extent of web-IR disclosure.

\section{Equity Need}

Lang and Lundholm (2000) argue that companies who access capital markets are more likely to increase their disclosure because increased disclosure is expected to reduce information asymmetry and hence reduce the cost of capital (Lang and Lundholm, 1993). It is also expected to increase investor confidence and decrease uncertainty and ambiguity about the company (Gibbins et al. 1990; Lang and Lundholm, 1993; Clarkson et al. 1994; and Frankel et al. 1995). The above discussion results in the following hypothesis (stated in the alternative form):

H10: Ceteris paribus, the need for external equity capital is positively related to the existence /extent of web-IR disclosure.

\section{METHODOLOGY}

\subsection{The Regression Model}

A multivariate logistic regression is used to test the hypotheses with respect to the existence or otherwise of a website. For only those companies that have such a website, an ordinary least squares regression (OLS) is then used to explore the hypotheses with respect to the level of disclosure. Both models take the form:

$W P / I F R=\alpha+\beta 1$ Size $+\beta 2$ Prof $+\beta 3 G O V+\beta 4 I N S T+\beta 5 N S+\beta 6 G P+\beta 7$ Age $+\beta 8 I T+B 9 A T+\beta 10 E N+e$

Where:

$W P \quad=$ web presence: 1 if website, 0 if no website.

IFR = internet disclosure index for companies with website.

Size $\quad=$ market capitalization as end of 2006 .

Prof = Profitability, measured as return on equity for the year 2006.

GOV =Proportion of shares (if $5 \%$ or more) owned by the government of Jordan as disclosed at the end of $2006^{[4]}$.

INST = Proportion of shares (if 5\% or more) owned by institutional shareholders as disclosed at the end of 2006.

NS = Number of shareholders, measured by log of number of shareholders of company x minus log of mean of number of shareholders for companies in the same asset deciles.

$G P \quad=$ growth prospects, measured as market value / book value at the end of 2006.

Age = number of years from establishment until the end of the year 2006.

$A T \quad=$ auditor type; 1 if big four auditing firm and 0 otherwise. 


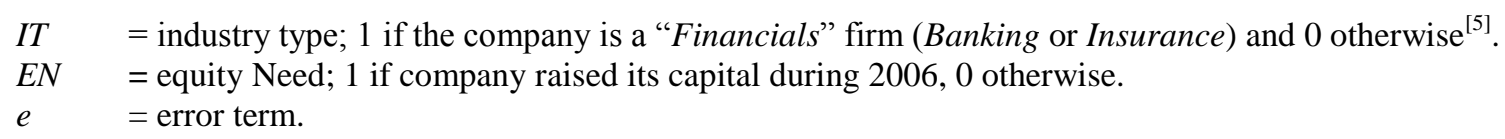

\subsection{Disclosure Measurement}

Following an initial review of a number of the websites of Jordanian companies it was decided to categorize disclosure practices into three types. Firstly, general items (13 items) which include items that, while not of direct relevance to investors, are expected to be present on any website to aid all users and encourage feedback from them. These include such things as a search engine, site language, site map, and general email address. Secondly, financial report items (45 items) which may be found in either the annual or interim reports. Thirdly, internet technology items (12 items) which capture the use of internet technology such as the latest share prices, email alerts and video and audio broadcasting.

While, with a few exceptions (e.g., Marston and Polei, 200; Bollen et al., 2006), prior IFR studies have not weighted the items, this study uses a weighted approach in order to assess not only what is disclosed, but also a company's efforts to present IR information in a user friendly manner. Therefore, the items are weighted in the following manner:

$W E B-I R=1.0$ (general items) +1.5 (financial report related information if disclosed as part of a single annual or interim document only) +2.0 (financial report related information if disclosed as a separate file or item only) +2.5 (financial report related information if disclosed in both locations) +3 (use of internet technology items) .

\subsection{Sample Companies}

Website addresses are acquired for the 195 actively traded companies from the Jordanian Securities Depository Centre (SDC) home page. In addition, search engines such as Google and Yahoo are also used. Eight companies are excluded from the analysis, 6 private universities and 2 daily newspapers because, while they have websites, these are not the parent company's website. After excluding these, 129 companies $(68.9 \%$ of the sample) have website addresses, but only 105 (or 56\%) of these are active, as at October 2007, as shown in Table 1.

Table 1: online status of sample companies

\begin{tabular}{|l|c|c|c|c|c|}
\hline \multirow{2}{*}{\multicolumn{1}{c|}{ Industry }} & \multirow{2}{*}{$\begin{array}{c}\text { No website } \\
\text { address }\end{array}$} & Not Active & Active & Under construction & Total \\
\cline { 3 - 6 } & 0 & 0 & 15 & 0 & 15 \\
\hline Banking & 6 & 1 & 16 & 2 & 25 \\
\hline Insurance & 29 & 8 & 40 & 4 & 81 \\
\hline Services & 23 & 5 & 34 & 4 & 10 \\
\hline Manufacturing & 58 & 14 & 105 & 187 \\
\hline Total & & & & & 10 \\
\hline
\end{tabular}

\section{RESULTS}

\subsection{Disclosure Practices}

Eighty websites $(76 \%)$ disclose at least one piece of information related to IR. However, only 40 websites (38\%) have a specific IR section entitled investor relations or an equivalent such as financials, financial information, financial statements, or shareholder information. Table 2 presents the results of the survey. Reflecting both the importance of foreign investors and the use of English amongst the business class in Jordan (Omar, 2007), most companies have an English website (98\%) while far fewer (49\%) have an Arabic language website. More specifically, only $2 \%$ have only an Arabic language website, $48 \%$ have versions of websites in Arabic and English, and 53\% have one version of the website in English only. Interestingly, this indicates a marked increase in the proportion of companies with an English language web site over earlier periods (Al-Htaybat, 2005). 
Given that only $38 \%$ of companies have a specific IR section on their website; it is not surprising to find that the level of disclosure of all of the IR-related information is low. Most common is information on the board of directors, followed by a mission statement. While the web sites were investigated in October 2007, 34\% of companies made their 2005 income statement and statement of financial position available, but only $29 \%$ did so for 2006. Other financial information such as notes, cash flow statements and auditor's report were less common, reflecting the fact that very few companies made their complete set of annual accounts available on the web site.

However, despite these relatively low levels of disclosure, the disclosure of IR information on corporate websites is concentrated in the one way communication of historical information with websites being used to publishing information which usually appears in paper based annual report. Thus, while $51 \%$ of companies used their websites to publicise news, only $5 \%$ disclosed their share price, $14 \%$ provided a link to the ASE share price ticker tape and $6 \%$ had video or audio presentations.

Table 2: Results of the survey analysis

\begin{tabular}{|c|c|c|c|}
\hline 1. General information on the websites & $\%$ & & \\
\hline Arabic version of the site & 49 & Statement of financial position ( 2005) & 34 \\
\hline English version of the site & 98 & Income statement (2005) & 34 \\
\hline Brief history of the company & 96 & Cash flow statement (2005) & 26 \\
\hline Search engine & 30 & statement of changes in owner equity (2005) & 25 \\
\hline Site map & 31 & Segmental reporting (2005) & 14 \\
\hline Contact Info & 98 & Key financial ratios (2005) & 20 \\
\hline General e-mail address & 90 & Shareholders profile & 5.7 \\
\hline Feed back about the site & 15 & major shareholders & 17 \\
\hline General Enquiry Form & 48 & numbers of shares owned by Directors & 15 \\
\hline Frequently asked questions (General) & 19 & numbers of shares owned by senior management & 15 \\
\hline online business services & 25 & corporate social responsibility & 19 \\
\hline job opportunity & 33 & Environmental reporting & 13 \\
\hline Products and services provided by the company & 100 & Mission statements & 45 \\
\hline \multirow[b]{2}{*}{ 2. IR-related information } & & Vision statement & 40 \\
\hline & & Chairman's letter & 32 \\
\hline \multirow[b]{2}{*}{ 2.1 Financial report related information: } & & future plans & 23 \\
\hline & & board of directors' report & 18 \\
\hline $\begin{array}{l}\text { Names of the members of the board of } \\
\text { directors }\end{array}$ & 58 & frequently asked questions (financial topics) & 0 \\
\hline Brief back ground about the board of Directors & 21 & Organizational structure & 28 \\
\hline Names of senior executives & 37 & Share price performance Tables & 7.6 \\
\hline Brief background about senior executives & 21 & share price performance Graphs & 7.6 \\
\hline Disclosure about audit committee & 12 & Financial performance Graphic images & 19 \\
\hline Disclosure about executive committee & 5.7 & & \\
\hline Disclosure about internal controls & 9.5 & \multirow[b]{2}{*}{ 3. Use of internet technology } & \\
\hline Disclosure about risk management & 14 & & \\
\hline Disclosure about remuneration committee & 2.8 & Latest stock price & 5 \\
\hline Board compensation and benefits & 14 & Board of Directors share Trading (Updated) & 2 \\
\hline Senior executive managers compensation & 14 & video/audio presentations & 6 \\
\hline Employees profile & 17 & Video/Audio broadcasting of historical AGM & 1 \\
\hline Statement of financial position (Year 2006) & 29 & Emails alerts and updates (mailing list) & 15 \\
\hline Income statement (Year 2006) & 29 & Company's Latest news & 51 \\
\hline Cash flow statement (Year 2006) & 22 & Investor relations calendar & 1 \\
\hline statement of changes in owner equity (2006) & 22 & Hyperlinked accounting data & 2 \\
\hline Segmental reporting (Year 2006) & 12 & animated graphics & 0 \\
\hline Selected accounting data (Year 2006) & 22 & link to ASE, JSC or SDC & 15 \\
\hline Key financial ratios (Year 2006) & 19 & data provided in processable format & 0 \\
\hline Auditor's Report (Year 2006) & 20 & ASE share price ticker tape (shows updated prices) & 14 \\
\hline Notes to Accounting Data (Year 2006) & 22 & Interactive IR email address & 4 \\
\hline Interim reports (Year 2007) & 9 & Investors' forums & 1 \\
\hline time series of selected accounting data & 21 & Online conferences & 0 \\
\hline
\end{tabular}




\subsection{Website Presence and Company Characteristics}

Univariate analyses are conducted to find if corporate characteristics are different according to their website presence. Accordingly, companies are divided into two groups. The first includes 115 companies with active websites (105 companies) or under construction websites (10 companies); while the second group includes 67 companies with no websites (53 companies) or no active websites (14 companies).

Seven continuous variables are examined and two tests of locations are employed; the parametric test of means (T-test) and non-parametric test of medians (Mann-Whitney test) ${ }^{[6]}$. As reported in Table 3, companies with corporate websites are larger, on average, than companies with no websites (mean market capitalizations 159 and 31.7 million JD respectively, significant at $10 \%$, while Man-Whitney is significant at $1 \%$ ). Similarly, government ownership of companies with corporate websites is higher, on average, than other companies. Both tests of means and medians show that this difference is significant at the 5\% level. Finally, companies with websites are more profitable, on average, than other companies (mean scores of ROE are 0.028 and 0.005 respectively). However, while the non-parametric test revealed that this difference is significant at the 5\% level, it is not significant according to the parametric analysis $(t=0.997, p=0.320)$. No significant relationships are found between online presence and other continuous variables.

Table 3: Parametric and non-parametric tests for continuous variables

\begin{tabular}{|c|c|c|c|c|c|c|c|c|}
\hline \multirow{3}{*}{ Variable***** } & \multicolumn{4}{|c|}{ Parametric analysis } & \multicolumn{4}{|c|}{ Non-parametric analysis } \\
\hline & \multicolumn{2}{|c|}{ Means } & \multicolumn{2}{|c|}{ Test of means (Ttest) } & \multicolumn{2}{|c|}{ Mean rank } & \multicolumn{2}{|c|}{$\begin{array}{c}\text { Test of medians } \\
\text { (Mann-Whitney test) }\end{array}$} \\
\hline & $\begin{array}{c}\text { With } \\
\text { website } \\
(n=115)\end{array}$ & $\begin{array}{c}\text { Without } \\
\text { website } \\
(n=67)\end{array}$ & T test & P-value & $\begin{array}{c}\text { With } \\
\text { website } \\
(n=115)\end{array}$ & $\begin{array}{c}\text { Without } \\
\text { website } \\
(n=67)\end{array}$ & Z score & P-value \\
\hline Size & 159 (million) & 31.7 (million) & $1.835 \dagger$ & 0.069* & 105.19 & 68 & -4.593 & $0.000 * * *$ \\
\hline Prof & 0.0285 & 0.0059 & $0.997 \dagger$ & 0.320 & 99.13 & 78.41 & -2.558 & $0.011 * *$ \\
\hline GOV & 0.0333 & 0.0122 & $2.335 \dagger$ & $0.021 * *$ & 96.05 & 83.69 & -2.300 & $0.021 * *$ \\
\hline INST & 0.3714 & 0.3668 & $0.114 \dagger$ & 0.910 & 91.55 & 91.42 & -0.016 & 0.987 \\
\hline$N S$ & 3895.13 & 2498.52 & $1.464 t$ & 0.145 & 96.03 & 83.73 & -1.518 & 0.129 \\
\hline Age & 20.73 & 17.84 & $1.255 \ddagger$ & 0.211 & 94.97 & 85.55 & -1.165 & 0.244 \\
\hline$G P$ & 1.896 & 1.9663 & $-0.349+$ & 0.727 & 95.17 & 85.19 & -1.233 & 0.218 \\
\hline
\end{tabular}

* Significant at the $10 \%$ level.

$* *$ Significant at the $5 \%$ level.

*** Significant at the $1 \%$ level.

**** Variable definitions are reported in Section 4.1.

$\uparrow$ Equal variances are not assumed.

\$ Equal variances are assumed.

Chi-square tests of differences in proportions are carried out on the dichotomous variables (untabulated), namely: Industry Type, Auditor Type, and Equity Need. Looking firstly at industry and splitting the sample into four industries (Banking, Insurance, Services, and Manufacturing) reveals that corporate online presence varies significantly across industries (Pearson Chi-square $=11.514, \mathrm{P}=0.009$ ). Additional chi-square tests confirm that the "Financials" industry (Banking and Insurance) differs significantly between the groups compared (Pearson chisquare $=7.104, p=0.006$ ). In addition, there is a significant relationship between "Equity Need" and "Auditor Type" and corporate website presence (Pearson chi-square $=6.847, \mathrm{p}=0.009$; and Pearson chi-square $=6.999, \mathrm{p}=$ 0.008 respectively). Chi-square results suggest that companies belonging to the "Financials" industry, companies that are audited by Big 4 firms and companies that raise external equity capital are more likely to have corporate websites. While univariate differences exist, the multivariate regression offers advantages over this comparison because it controls for the effects and interrelationships between other independent variables and is deemed to be more robust than univariate analyses in detecting significant relationships between the dependent and independent variables. Therefore, the multivariate results are given greater consideration in this study. 
Multivariate analysis is conducted using logistic regression analysis or logit. Logit is theoretically attractive because there are no assumptions regarding linearity or normality of data (Field, 2005). However, there are a number of potential problems that must be considered before logit regression is carried out. Outliers and influential cases can substantially affect results. However, no Cook value is greater than 1.0 and no standardised residual greater than 3.0, indicating no problem (Field, 2005: Hosmer and Lemeshow, 2000). The variables are also checked for heteroscedasticity which may cause the parameter estimates to be inconsistent, however, this is not found to be a problem. Finally, the highest pair-wise correlation coefficient is between size and profitability (0.372 Pearson correlation co-efficient, 0.484 Spearman correlation co-efficient) (untabulated) and the highest VIF $^{[7]}$ is 2.313 (for company size) indicating that multicollinearity is not a problem.

Results of the logit are reported in Table 4 . The adjusted $\mathrm{R}^{2}$ is calculated ${ }^{[8]}$ as $17.63 \%$. While $71 \%$ of cases are correctly predicted, only two variables are found to be significant, namely size and industry type (Financials) suggesting that larger companies and companies belonging to the "Financials" industry are more likely to have websites.

Table 4: Results of the logistic regression analysis

\begin{tabular}{|c|c|c|c|c|}
\hline \multicolumn{5}{|l|}{ Number of observations: 182} \\
\hline $\begin{array}{l}\text { Chi-squared }=42.243 \\
\text { Restricted Log Likelihood Function }=-119.748\end{array}$ & \multicolumn{2}{|c|}{ Significance level $=0.000$} & Log likelihood function $=-96.626$ & \\
\hline Independent variables $* * *$ & Fxnected sion & $\overline{\bar{B}}$ & B/Std Frror & P-value \\
\hline Intercept & & -17.786 & -2.927 & 0.003 \\
\hline Size & + & 1.111 & 2.953 & $0.003 * *$ \\
\hline Prof & $?$ & -1.070 & -0.480 & 0.631 \\
\hline GOV & + & 1.380 & 0.269 & 0.788 \\
\hline INST & + & 0.419 & 0.417 & 0.677 \\
\hline$N S$ & + & -0.513 & -1.095 & 0.274 \\
\hline Age & - & 0.001 & 0.048 & 0.962 \\
\hline$G P$ & $?$ & -0.305 & -1.370 & 0.171 \\
\hline$I T$ & + & 1.715 & 1.848 & $0.065 *$ \\
\hline$A T$ & + & 0.4511 & 0.587 & 0.557 \\
\hline$E T$ & + & -0.071 & -0.123 & 0.902 \\
\hline \multicolumn{5}{|l|}{ Disturbance variation term } \\
\hline \multicolumn{2}{|l|}{ F1 } & 2.854 & 2.085 & 0.037 \\
\hline \multicolumn{5}{|l|}{ Frequencies of actual and predicted outcomes: } \\
\hline & \multicolumn{4}{|c|}{ Predicted } \\
\hline Actual & 0 & 1 & Total & $\%$ \\
\hline 0 & 32 & 36 & 67 & 48 \\
\hline 1 & 17 & 98 & 115 & 85 \\
\hline Total & 49 & 133 & 182 & 71 \\
\hline
\end{tabular}

* Significant at the $10 \%$ level, ** significant at the $1 \%$ level.

*** Variable definitions are reported in Section 4.1 .

\subsection{Web-site Usage and Corporate Characteristics.}

To measure the extent of disclosure on websites, a disclosure index is developed as explained in Section 4.2. Kolmogorov-Smirnov (K-S) normality test, Pearson and Spearman correlation matrices, VIF and scatter plots of residuals against the predicted values indicate that the data are not normally distributed and problems of heteroscedastisity exist. Accordingly, and following Abdelsalam et al (2007), all continuous variables are transformed using both percentile ranks ${ }^{[9]}$ and normal scores ${ }^{[10]}$ methods. Table 5 presents the results of the regression analyses using the transformed data. The rank transformation is marginally more successful with an adjusted $R^{2}$ of $0.439(F=9.15, \mathrm{p}=.0000)$ instead of $0.423(\mathrm{~F}=8.64, \mathrm{p}=0.000)$. The Durbin-Watson d statistic is very close to 2 in both models, providing no evidence of first-order autocorrelation. 
As for the explanatory variables, the analysis is very similar for the two models. In both cases, size is a significant positive indicator of web-IR disclosures, supporting hypothesis H1. However, while this is consistent with agency theory, signalling theory and cost-benefit analysis, it is only significant at the $10 \%$ level. In contrast, variables related to ownership structure are found to be more significant, supporting hypotheses $\mathrm{H} 3$ and $\mathrm{H} 4$. The significant and positive relationship (at $1 \%$ level) between government ownership and company's web-IR disclosures provides strong support for the Coercive isomorphism of the institutional theory. This suggests that companies with a higher proportion of shares owned by the government react more to recent governmental initiatives regarding ICT, and as a result these companies have higher levels of web-IR disclosure. While the relationship is not as strong, institutional ownership also have a significant positive relationship with the disclosure index supporting the professionalism isomorphism of the institutional theory. Similar to the size variable, the number of shareholders has a significant and positive relationship with the dependent variable in both models. This result is also consistent with the agency theory argument, suggesting that increased disclosure may be seen as a suitable response to reduce potential conflict between shareholders and management. Younger companies are also more likely to be engaged in web-IR disclosures, although this variable is significant only for the rank transformation. This result supports the diffusion of innovation theory, and supports hypothesis H8 suggesting that younger companies are more flexible in accepting and adopting new technologies. In addition, it is argued that disclosure can be used to reduce uncertainty (Haniffa, 1999) and it may be that newly listed companies disseminate more information than older listed firms in order to reduce uncertainty about their operations and increase investors' confidence (Omar, 2007). Finally, the results strongly support the mimetic isomorphism of the institutional theory. Companies in the "Financials" industry use the internet significantly more than do companies in other industries. This is likely to be related to both competition levels and overseas transactions aiming to achieve higher levels of transparency and information availability.

On the other hand, independent variables related to profitability, growth prospects, auditor type, and equity need are not found to be significant. Accordingly, hypotheses H2, H7, H9, and $\mathrm{H} 10$ are all rejected.

Table 5: Results of the OLS multiple regression analysis

\begin{tabular}{|c|c|c|c|c|c|c|c|}
\hline \multirow{5}{*}{\begin{tabular}{|l|} 
\\
Model \\
statistics
\end{tabular}} & & \multicolumn{3}{|c|}{ Normal scores } & \multicolumn{3}{|c|}{ Rank transformation } \\
\hline & F Value & \multicolumn{3}{|c|}{8.64} & \multicolumn{3}{|c|}{9.15} \\
\hline & P-value & \multicolumn{3}{|c|}{0.000} & \multicolumn{3}{|c|}{0.000} \\
\hline & Adj. $\mathbf{R}^{2}$ & \multicolumn{3}{|c|}{0.423} & \multicolumn{3}{|c|}{0.4394} \\
\hline & DW & \multicolumn{3}{|c|}{1.807} & \multicolumn{3}{|c|}{1.982} \\
\hline \multicolumn{2}{|c|}{$\overline{~ I n d e p e n d e n t ~ v a r i a b l e s * * * * * ~}$} & $\overline{\mathbf{B}}$ & $\begin{array}{l}\text { P-value } \\
\end{array}$ & 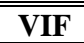 & $\overline{\mathbf{B}}$ & $\begin{array}{l}\text { P-value } \\
\end{array}$ & 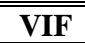 \\
\hline \multicolumn{2}{|l|}{ Intercept } & -0.2808 & 0.0223 & & 0.1420 & 0.1153 & \\
\hline \multicolumn{2}{|l|}{ Size } & 0.2040 & $0.0815 *$ & 2.979 & 0.19566 & $0.0778^{*}$ & 2.721 \\
\hline \multicolumn{2}{|l|}{ Prof } & -0.0015 & 0.9846 & 1.348 & -0.01810 & 0.8209 & 1.391 \\
\hline \multicolumn{2}{|l|}{ GOV } & 0.2795 & $0.009 * * *$ & 1.306 & 0.2734 & $0.0039 * * *$ & 1.243 \\
\hline \multicolumn{2}{|l|}{ INST } & 0.1705 & $0.0329 * *$ & 1.244 & 0.1293 & $0.0942 *$ & 1.265 \\
\hline \multicolumn{2}{|l|}{$N S$} & 0.2029 & $0.0220 * *$ & 1.702 & 0.1868 & $0.0218 * *$ & 1.501 \\
\hline \multicolumn{2}{|l|}{ Age } & -0.0853 & 0.2923 & 1.466 & -0.2172 & $\mathbf{0 . 0 0 4 8} * * *$ & 1.339 \\
\hline \multicolumn{2}{|l|}{$G P$} & -0.0617 & 0.4771 & 1.300 & -0.03564 & 0.6649 & 1.294 \\
\hline \multicolumn{2}{|l|}{$I T$} & 0.9989 & $0.0001 * * *$ & 1.731 & 0.3214 & $0.000 * * *$ & 1.790 \\
\hline \multicolumn{2}{|l|}{$A T$} & 0.1269 & 0.5387 & 1.765 & 0.04919 & 0.3695 & 1.677 \\
\hline \multicolumn{2}{|l|}{$E T$} & 0.1288 & 0.3834 & 1.180 & 0.06612 & 0.1482 & 1.196 \\
\hline
\end{tabular}

* Significant at the $10 \%$ level, ** significant at the 5\% level, *** significant at the $1 \%$ level.

**** Variable definitions are reported in Section 4.1.

Using a multi-theoretical approach, this study examines the determinants of corporate web-based investor relations (IR) activities for companies listed on the Jordanian Amman Stock Exchange . Notwithstanding the numerous efforts and initiatives exerted by the government of Jordan to encourage individuals and companies to engage in the cyber world, low levels of online presence are reported. Results reveal that online activities are concentrated in the one-way communication stage. More specifically, companies use their websites to disseminate 
information to shareholders rather than creating a dialogue. In addition, it is found that contents of websites are static and the advantages of the internet to publish up-to-date information as well as the potentials to use video, audio, and graphic presentation are not fully utilized. Instead, companies limit themselves in the lowest level of internet reporting to disseminate historical information, which can be achieved by any paper-based documents.

Results of the logistic regression used to test for the existence of web-IR activities reveal that size and industry type (Financials) are the only significant determinants. Companies in the "Banking" and "Insurance" industries operate in an increasingly international and highly competitive industry. Not only is online banking becoming increasingly important, but such companies need access to the international financial markets. In contrast, for companies operating in other industries, the pressures or incentives to report to shareholders or others interested in the financial performance of the company may not be enough, by themselves, to convince the company to set-up a corporate web-site. This suggests that the motivation to set-up a corporate web site in Jordan may be primarily customer or institutional-based rather than depending on firm-specific characteristics.

Results of the OLS regressions used to test for the extent of web-IR activities reveal that corporate online reporting practices are influenced by institutional pressures, cost-benefit analysis and innovations diffusion perspectives. Institutional pressures can be seen from coercive isomorphism pressures (Government ownership), mimetic isomorphism pressures (industry type), and normative isomorphism pressures (institutional ownership). Also, the significant and positive influence of the number of shareholders may be viewed from a cost-benefit perspective. On the other hand, results related to company age and size are consistent with the diffusion of innovations propositions.

This study should be of interest to regulators in Jordan as it offers valuable insights into the characteristics of those companies that do and do not meet national and international investors' demands for online information. It also assists current and potential stakeholders to know the drives of web-IR activities in the Jordanian context which has not been extensively examined before. The paper also demonstrates the usefulness of theoretical triangulation in explaining web-based IR disclosures. This study is based on Jordan practices as an example of an emerging economy; practices in other countries and international comparisons of determinants of web-based IR activities are useful in the development of a comprehensive predictive model for the choice of web-based IR activities.

\section{AUTHOR INFORMATION}

Naser M. AbuGhazaleh*(Corresponding Author) is an Assistant Professor in Accounting at Gulf University for Science and Technology (GUST), Kuwait. He received his PhD in Accounting from Aberdeen University, UK. His research interests are in the areas of Financial Reporting, Value Relevance of Accounting Information, Internet Financial Reporting, Corporate Governance, Earning Management, Accounting for Goodwill and Asset Impairments. His research also includes investigating the relation between Corporate Governance and Earnings Management aiming to explore how governance mechanisms affect firms' decision making. E-mail: Abughazaleh.n@gust.edu.kw. Corresponding author.

Amer Qasim is an Assistant Professor of Accounting at the American University of Madaba in Jordan. He received his $\mathrm{PhD}$ in Accounting from Aberdeen University, UK. His research interests are in the areas of Internet Financial Reporting, Voluntary Disclosure, Investor Relations and Value Relevance of Accounting Information. E-mail: qasemamer@hotmail.com.

Clare Roberts is a professor of Accounting at The University of Aberdeen Business School. She received her PhD from the University of Glasgow. U.K. Her research interests are in the area of international accounting and financial accounting. She is particularly interested in financial accounting and reporting practices and explanations of differences both internationally and domestically. This includes for example the impact of the IASB on accounting harmonization, explanations of corporate accounting choices and reporting practices including segment reporting, voluntary financial and non-financial disclosures, internet reporting and image presentation. E-mail: c.roberts@abdn.ac.uk. 


\section{Notes}

[1] Internet World Stats: Usage and Population Statistics - Middle East States: Jordan, http://www.internetworldstats.com/me/jo.htm [date accessed: 15/07/2009].

[2] While this may be a promising line of research, problems of data availability make it unfeasible in Jordan.

[3] Bushee et al. (2003) formed size deciles according to sales and total assets. They conclude that forming size deciles using market capitalization yields weaker results especially as multicollinearity occurs when models include a variable for size measured as market value of equity.

[4] The Stock Exchange discloses significant shareholdings only.

[5] In the sample set all companies belonging to the "Banking" industry have a website so this variable perfectly predicts the dependent variable in regression analysis. The "Banking" and "Insurance" industries are therefore combined in the analysis to form a "Financials" industry variable.

[6] The continuous variables are not normally distributed; hence results related to test of medians are more reliable

[7] To obtain VIF, a linear regression analysis using the same variable is run (Field, 2005).

[8] This is calculated as Chi-square/ ( $2 *$ restricted log likelihood function) (Field, 2005)

[9] The approach of rank transformation as suggested by Cheng et al. (1992) is adopted where ranks are standardized by the number of observations plus $1(\mathrm{~N}+1)$ so that the ranked variable has a maximum value of $\mathrm{N} /(\mathrm{N}+1)$ and a minimum of $1 /(\mathrm{N}+1)$.

[10] Following Cooke (1998) the Van der Warden approach is employed and the ranks are substituted by scores on the normal distribution, by dividing the distribution into the number of observations plus one region on the basis that each region has equal probability.

\section{REFERENCES}

1. Abdelsalam, O. H. and El-Masry, A. (2008), 'The impact of board independence and ownership structure on the timeliness of corporate internet reporting of Irish-listed companies', Managerial Finance 34 (12), pp. 907-918.

2. Abdelsalam, O. H. Bryant, S. M. and Street, D. L. (2007), 'An examination of the comprehensiveness of corporate internet reporting provided by London-listed companies', Journal of International Accounting Research, 6 (2), pp. 1-33.

3. Abdelsalam, O. and Street, D. L. (2007), 'Corporate governance and timeliness of corporate internet reporting by U.K. listed companies’, Journal of International Accounting, Auditing and Taxation, 16, pp. 111-130.

4. Adams, C. and Frost, G. (2004), The Development of Corporate Web-Sites and Implications for Ethical, Social and Environmental Reporting Through These Media, The Institute of Charted Accountants of Scotland, Edinburgh.

5. Al-Htaybat, K. (2006), Financial Disclosure Practices: Theoretical Foundation, and an Empirical Investigation on Jordanian Printed and Internet Format, Unpublished Doctoral Thesis. University of Southampton, UK.

6. Al-Jaghoub, S. and Westrup, C. (2003), 'Jordan and ICT-led development: towards a competition state', Information Technology and People 16 (1), pp. 93-110.

7. Aly, D. Simon, J. and Hussainey, K. (2010), 'Determinants of corporate internet reporting: evidence from Egypt', Managerial Auditing Journal, 25 (2), pp. 182-202.

8. Ashbaugh, H. Johnston, K. M. and Warfield, T. D. (1999), 'Corporate reporting on the internet', Accounting Horizons, 13(3), pp. 241-257.

9. Bart, C. K. (2001), 'Exploring the application of mission statements on the world wide web', Internet Research 11(4), pp. 360-368.

10. Beattie, V. and Pratt, K (2001), Business Reporting: Harnessing the Power of the Internet for Users, ICAS, Edinburgh.

11. Beattie, V. and Pratt, K. (2003), 'Issues concerning web-based business reporting: an analysis of the views of interested parties', The British Accounting Review, 35, pp. 155-187. 
12. Bollen, L. Hassink, H. and Bozic, G. (2006), 'Measuring and explaining the quality of internet investor relations activities: a multinational empirical analysis', International Journal of Accounting Information Systems 7(4), pp. 273-298.

13. Bonson, E. and Escobar, T. (2006), 'Digital reporting in Eastern Europe: an empirical study', International Journal of Accounting Information Systems, 7, pp. 299-318.

14. Brennan, N. and Hourigan, D. (2000), 'Corporate reporting on the internet by Irish companies', The Irish Accounting Review, 7(1), pp. 37-68.

15. Brennan, N. and Kelly, S. (2000), 'Use of the internet by Irish companies for investor relations purposes', Journal of the Irish Academy of Management 21(2), pp. 107-135.

16. Bushee, B. Matsumoto, D. and Miller, G. (2003), 'Open versus closed conference calls: the determinants and effects of broadening access to disclosure', Journal of Accounting and Economics, 34, pp. 149-180.

17. Chan, W. K. and Wickramasinghe, N. (2006), 'Using the internet for financial disclosure: the Australian experience', International Journal of Electronic Finance 1(1), pp. 118-150.

18. Cheng, C.S.A. Hopwood, W.S. and McKewon, J.C. (1992), 'Non-linearity and specification problems in unexpected earnings response regression mode', The Accounting Review, 67(3), pp. 579-598.

19. Chow, C.W. (1982), 'The demand for external auditing: size, debt, and ownership influences', The Accounting Review, 57 (2), pp. 272-291.

20. Ciborra, C. and Navarra, D. (2005), 'Good governance, development theory, and aid policy: risks and challenges of E-Government in Jordan', Information Technology for Development, 11(2), pp. 141-159.

21. Clarkson, P.M. Kao, J.L. Richardson, G.D. (1994), 'The voluntary inclusion of forecasts in the MD \& A section of annual reports', Contemporary Accounting Research, 11(1), pp. 423-450.

22. Craven, B. M. and Marston, C.L. (1999), 'Financial reporting on the internet by leading UK companies', The European Accounting Review, 8(2), pp. 321-333.

23. Debreceny, R. and Gray, G. L. (1999), 'Financial reporting on the internet and the external audit', The European Accounting Review, 8(2), pp. 335-350.

24. Debreceny, R. Gray, G. L. and Rahman, A. (2002), 'The Determinants of Internet Financial Reporting', Journal of Accounting and Public Policy, 21, pp. 371-394.

25. Deller, D. Stubenrath, M. and Weber, C. (1999), 'A survey on the use of the internet for investor relations in the USA, the UK and Germany', The European Accounting Review, 8(2), pp. 351-364.

26. Desoky, A.M. (2009), 'Company characteristics as determinants of internet financial reporting in emerging markets: the case of Egypt', Research in Accounting in Emerging Economies, 9, pp. 31-71.

27. DiMaggio, P.J. and Powell, W.W. (1983), 'The iron cage revisited: institutional isomorphism and collective rationality in organizational fields', American Sociological Review, 48, pp. 147-160.

28. Ettredge, M. Richardson, V. J. and Scholz, S. (2001), 'The presentation of financial information at corporate web sites', International Journal of Accounting Information Systems, 2, pp. 149-168.

29. Ettredge, M. Richardson, V. J. and Scholz, S. (2002), 'Dissemination of information for investors at corporate web sites', Journal of Accounting and Public Policy, 21, pp. 357-369.

30. FASB (2000), Business Reporting Research Project: Electronic Distribution of Business Information, Financial Accounting Standards Board. Steering Committee Report Series.

31. Ferguson, M.J. Lam, K.C. and Lee, G.M. (2002), 'Voluntary disclosure by state-owned enterprises listed in the stock exchange of Hong Kong', Journal of International Financial Management and Accounting, 13 (2), pp. 125-148.

32. Field, A. (2006), Discovering Statistics Using SPSS, Second edition. SAGE Publications. London.

33. Flanagin, A. J. (2000), 'Social pressures on organizational website adoption', Human Communication Research, 26 (4), pp. 618-646.

34. Francis, J.R. and Wilson, E.R. (1988), 'A joint test of theories relating to agency costs and auditor differentiation', The Accounting Review, 63 (4), pp. 663-682.

35. Frankel, R. McNichols, M. and Wilson, G.P. (1995), 'Discretionary disclosure and external financing', The Accounting Review, 70 (1), pp. 135-150.

36. Geerings, J. Bollen, L.H.H. and Hassink, H.F.D. (2003), 'Investor relations on the internet: a survey of the Euronext zone', The European Accounting Review, 12(3), pp. 567-579.

37. Gibbins, M. Richardson, A. and Waterhouse, J. (1990), 'The management of corporate financial disclosure: opportunism, ritualism, and processes', Journal of Accounting Research, 28 (1), pp. 121-143. 
38. Giner, B. (1997), 'The influence of company characteristics and accounting regulation on information disclosed by Spanish firms', The European Accounting Review, 16 (1), pp. 45-68.

39. Gowthorpe, C. and Amat, O. (1999), 'External reporting of accounting and financial information via the internet in Spain', The European Accounting Review, 8 (2), pp. 365-371.

40. Haniffa, R. M. (1999), 'Culture, Corporate Governance and Disclosure in Malaysian Corporations', Unpublished PhD Thesis, University of Exeter.

41. Haniffa, R. M. and Cooke, T.E. (2002), 'Culture, corporate governance and disclosure in Malaysian companies', Abacus, 38 (3), pp. 317-349.

42. Healy, P. and Palepu, K. (2001), 'Information Asymmetry, corporate disclosure, and the capital markets: A review of the empirical disclosure literature', Journal of Accounting and Economics, 31, pp. 405-440.

43. Hedlin, P. (1999), 'The internet as a vehicle for investor relations: the Swedish case', The European Accounting Review, 8 (2), pp. 373-381.

44. Hodge, F.D. (2001), 'Hyperlinking Unaudited Information to Audited Financial Statements: Effects on Investors Judgments', The Accounting Review, 76(4), pp. 675-691.

45. Hosmer, D. W. and Lemeshow, S. (2000), Applied Logistic Regression, Second edition. John Wiley and Sons, Inc. New York.

46. Hussainey, K. and Al-Nodel, A. (2008), 'Corporate governance on-line reporting by Saudi listed companies’, Research in Accounting in Emerging Economies, 8, pp. 39-64.

47. Jordan Securities Commission, Seventh Annual Report (2006), Amman, Jordan.

48. Kelton, A. S. and Yang, Y. (2008), 'The impact of corporate governance on internet financial reporting', Journal of accounting and Public Policy, 27, pp. 62-87.

49. Lang, M. and Lunholm, R. (1993), 'Cross-sectional determinants of analysts ratings of corporate disclosures', Journal of Accounting Research, 31 (2), pp. 246-271.

50. Lang, M. and Lunholm, R. (2000), 'Voluntary disclosure and equity offerings: reducing information asymmetry or hyping the stock?' Contemporary Accounting Research, 17, pp. 623-662.

51. Lymer, A., Debreceny, R., Gray, G. L. and Rahman, A., (1999) Business Reporting on the Internet London: IASC.

52. Lymer, A. and Debreceny, R. (2003), 'The auditor and corporate reporting on the internet: challenges and institutional responses', International Journal of Auditing, 7, pp. 103-120.

53. Marston, C. (2003), 'Financial reporting on the internet by leading Japanese companies', Corporate Communications, 8(1), pp. 23-34.

54. Marston, C. and Polei, A. (2004), 'Corporate reporting on the internet by German companies', International Journal of Accounting Information Systems, 5, pp. 285-311.

55. Mohamed, E.K.A., Oyelere, P. and Al-Busaidi, M. (2009), 'A survey of internet financial reporting in Oman,' International Journal of Emerging Markets, 4(1), pp. 56-71.

56. Omar, B.F.A. (2007), Exploring the Aggregate, Mandatory, and Voluntary Financial Disclosure Behaviour Under A New Regulatory Environment: The Case Of Jordan, Unpublished Doctoral Thesis, University of Hull.

57. Oyelere, P. Laswad, F. and Fisher, R. (2003), 'Determinants of internet financial reporting by New Zealand listed companies, Journal of International Financial Management and Accounting, 14 (1), pp. 26-63.

58. Pirchegger, B. and Wagenhofer, A. (1999), 'Financial information on the internet: a survey of the homepages of Australian companies', The European Accounting Review, 8 (2), pp. 383-395.

59. REACH 1.0 (2000), Jordan's REACH Initiative, Lunching Jordan's Software and IT Industry, A Strategy and action Plan For H.M. King Abdullah II, Available at: http://www.reach.com.jo/reach_1_01.htm [Date Accessed 12/06/2009].

60. REACH 3.0 (2002), Jordan's REACH Initiative, Lunching Jordan's Software and ICT Services Industry, An Updated Strategy and action Plan For H.M. King Abdullah II, Available at: http://www.reach.com.jo/reach 3 01.htm [Date Accessed 12/06/2009].

61. Rogers, E. M. (1995), Diffusion of Innovations, Fifth Edition, Free Press, New York.

62. Suwaidan, M. S. (1997), 'Voluntary Disclosure of Accounting Information: The Case of Jordan', Unpublished Doctoral Thesis, University of Aberdeen, UK.

63. Wagenhofer, A. (2003), 'Economic Consequences of Internet Financial Reporting', Schmalenblach Business Review, 55, pp. 262-279.

64. Watts, R.L. and Zimmerman, J.L. (1986), Positive Accounting Theory, Prentice Hall: Englewood Cliffs. 
65. Winter, S. Saunders, J. and Hart, P. (2003), 'Electronic window dressing: impression management with websites', European Journal of Information Systems, 12, 309-322.

66. Xiao, Z. Jones, M.J. and Lymer, A. (2002), 'Immediate trends in internet reporting', The European Accounting Review, 11(2), pp. 245-275.

67. Xiao, J. Z. Yang, H. and Chow, C. W. (2004), 'The determinants and characteristics of voluntary internetbased disclosures by listed Chinese companies', Journal of Accounting and Public Policy, 23, pp. 191-225. 


\section{NOTES}

